\title{
PAX-Patios de la Axerquía Urban Regeneration and Social Innovation in a Heritage Context
}

\author{
Gaia Redaelli \\ School of Architecture and Society, Politecnico di Milano, Milan, Italy \\ Email: gaiaangelica.redaelli@polimi.it
}

\begin{abstract}
Following a decades-long real estate bubble involving a culture of indiscriminate ownership and occupation of land, PAX-Patios de la Axerquía is proposing an innovative system of governance in the city of Córdoba in Spain that fosters a new urban model consistent with the aims of the New Urban Agenda and a Smart, Sustainable and Inclusive City: from a culture of speculation to one of rehabilitation. A system of multilevel co-management between the public administration and the social economy provides the basis for the acquisition and cooperative use of empty houses as a model of urban regeneration through social innovation in a heritage context. The rehabilitation of the patio-houses in Axerquía, which have been threatened by gentrification, aims to restore the environmental values of the Mediterranean city and upgrade its historical characteristics in a contemporary way together with the citizenship: from its architectural value as a World Heritage site to its anthropological value as Intangible Heritage of Humanity, as recognised by UNESCO in 2012. The interaction between innovative mechanisms of sustainable urban development opens up a pathway of virtuous policies for the densification of the existing city by the local population, generation of micro-employment, and support for collective projects that incorporate refugees and migrants in a system of solidarity. Updating the urban, environmental, social, and economic values of the traditional city is a step toward understanding the Mediterranean city as an undeniable reminder of our past and, at the same time, providing an essential tool for the future development of a smart, sustainable, and inclusive Europe.
\end{abstract}

KEYWORDS urban rehabilitation, social innovation, gentrification, heritage, cooperative processes, Housing cooperatives

Received February 4, 2019; accepted March 12, 2019.

'Venice is priceless: because the invisible city intertwines every stone of its bridges, every drop of water in its canals is a dense knit of relationships, a powerful plot of facts and gestures, memories and words, of beauty and history.'

-Salvatore Settis, 2014

\section{Heritage and Gentrification}

Gentrification is a process involving the eviction of the residents in a specific neighbourhood, who are replaced by others with greater purchasing power. Introduced as a notion in England in the 1960s by the sociologist Ruth Glass, today gentrification is one of the most significant phenomena that affects the contemporary city so much so that, according to Neil Smith, the 'generalisation of gentrification' must be understood today as a 'global urban strategy' (Smith 2002). If the city has traditionally been the site of urban transformations determined by economic interests in the expanding city under the coordination of a public power or, in many cases private interests, today speculation has shifted towards places of greater historical interest, especially the central and heritage areas of our cities ${ }^{1}$.

The causes of this phenomenon are multiple, and affect both housing and services that determine the character and quality of an urban sector such as proximity or access to services for residents or visitors. On the one hand, gentrification is determined by the 'normal' dynamics of the real estate market, which changes the social fabric, while in other occasions it depends on the interest that financial funds have in finding new contents linked to the real 
estate market. On the other hand, gentrification has been the result, either directly or indirectly, of the actions of the public administration body, which has undertaken significant urban transformations or improvements of public spaces, resulting in an increase in housing prices and a consequent more or less unexpected change in residential dynamics. When the substitution of one population sector with another magnifies the change in use, for example from residential to tourism, this is a special form of gentrification that can be termed 'touristification'. If during the real estate bubble the game of speculation was played following expansive modes of urbanisation occupying territory and public space, today the 'new urban question'insofar as 'the social inequalities and their producing forms of evident spatial injustice '(Secchi 2013)_is played mostly in the consolidated city.

Thus, within the city, speculation not only affects the public space and collective services, but also intervenes in the homes of its inhabitants, especially in those cities that enjoy a greater architectural, urban and social heritage. The tourism industry, which is becoming increasingly influential in the world real estate market, is generating new formats that are extremely revolutionary in relation to the urban and contemporary social fabric. As the city is an urban and, at the same time, a social dimension where the majority of people lives, it is essential to define the formulas that guarantee not only the 'right to housing' for all citizens, but also the 'right to the city'. Introduced by Henry Lefebvre (1975), this notion has been recently nuanced by David Harvey towards a shared future in search of a more just model: the right to the city is 'much more than the right to individual or collective access to the resources it stores or protects; it is the right to change and reinvent the city in accordance with our wishes. It is also more a collective right than an individual right, since the reinvention of the city inevitably depends on the exercise of collective power over the urbanisation process' (Harvey 2012).

\section{The Social Value of Heritage}

Current urban transformations in world cities take place in strong connection to tourism, with heightened intensity in those places that have the greatest heritage, that is to say, the greatest tourism potential. Meanwhile, especially in Europe, the crisis that affected both the administration and the general public a decade ago provides fertile conditions for external funds to gain access to urban sectors in which an increasingly aged and impoverished population are forced to abandon its properties and sell to the highest bidder. This urban and social process has two main characteristics. First, it is practically irreversible, because it is very difficult for the local population to return to these areas following the inevitable price increases. Second, influencing areas of high historical interest, such as central urban areas, this phenomenon mostly affects the heart of cities and therefore not only the material heritage value, but also the intangible heritage and the way we live in our cities. Mis-configuring the balance between global economic interests and local cultural processes produces a homogenisation of our cities, and at the same time increases the risk of losing the social identity of our urban environments.

It is well-known that the concept of intangible heritage is based on the UNESCO's 'Convention for the Safeguarding of the Intangible Cultural Heritage' (2003), which states that 'The "intangible cultural heritage" means the practices, representations, expressions, knowledge, skills-as well as the instruments, objects, artefacts and cultural spaces associated therewith-that communities, groups and, in some cases, individuals recognise as part of their cultural heritage. This intangible cultural heritage, transmitted from generation to generation, is constantly recreated by communities and groups in response to their environment, their interaction with nature and their history, and provides them with a sense of identity and continuity, thus promoting respect for cultural diversity and human creativity.' Although it commonly overlaps with human productions linked to popular traditions-artistic, crafts, cultural-the intangible heritage is also recognised in the forms of coexistence and sharing that occur in the common space, especially in particularly intense environments such as cities. Hence, material heritage consists of not only buildings and monuments, but also parts of a city, such as neighbourhoods, and intangible heritage includes not only customs, but also ways of coexistence. Thus, heritage is, in this sense, a common good ${ }^{2}$.

Following the Paris Convention of 2003, the so-called Faro Convention was held in 2005 in the Portuguese city of Faro by the Council of Europe, the pan-European body that promotes cooperation among the European states to create common policies, especially in relation to human rights, democracy, and the rule of law. The 'Council of Europe Framework Convention on the Value of Cultural Heritage for Society', the official name of the Faro Convention, extended the content of the Paris Convention and the concept of heritage in accordance with innovative paradigms that aim to recognise its social value. First, the 
Convention affirms that cultural heritage is a resource for today and tomorrow, and not just a memory of the past. Second, the univocal relation between heritage conservation and public responsibility is broken by introducing the real citizen participation and co-management with the communities that give life to it. Finally, both the public administration and the citizens are invited to put into practice those actions that are able to alleviate the contradictions surrounding the heritage that may arise, for example, between its commercial/tourism value and its cultural/social value.

Among the definitions included in article two, the Faro Convention renewed the definition of 'cultural heritage', including the environment where people and places interact, and introduces a definition of a 'patrimonial community', those people who recognise a value from the past to transmit to the future:

1. Cultural heritage is a group of resources inherited from the past which people identify, independently of ownership, as a reflection and expression of their constantly evolving values, beliefs, knowledge and traditions. It includes all aspects of the environment resulting from the interaction between people and places through time;

2. A heritage community consists of people who value specific aspects of cultural heritage which they wish, within the framework of public action, to sustain and transmit to future generations ${ }^{3}$.

Proceeding from the references to pure knowledge, conservation, and dissemination enshrined in the 'Convention for the Protection of the Architectural Heritage of Europe' (Council of Europe 1985), the Faro Convention highlighted new challenges for territories and societies. By observing the actions of citizens adopting a bottom-up approach, the Council of Europe sought to identify good practices for generating a network of heritage communities through the Faro Convention Network and the implementation of its principles. The Faro Convention aimed to combine institutions and civil society in a harmonious manner based on a renewed notion of heritage. Rather that treating it as a purely conservative element from the past, and therefore as being of either a contemplative or mercantile/tourism nature, it would be transformed into something alive, that at the same time is the memory and the future of a community, and the main activator of a sustainable habitat. In short, the Faro Convention recognised the social dimension of heritage, viewing it a strategic resource in the push toward smart, sustainable, and inclusive growth.
If heritage is a common good, it seems necessary to rethink the relationship between the city and its people, as suggested by the Faro Convention, as one of co-responsibility and co-management that allows for the introduction of global dynamics without damaging local cultures (Saviani 2018). The Italian city of Venice is possibly the most representative example of the unsustainability of the heritage in speculative key linked to tourism that produces a separation between the city and its citizenship. The transformation of Venice into a theme park, mainly as a result of a tourism monoculture, is an excellent example of the risk that historic European cities face. Venice, with its delicate structure and narrow streets, has experienced an inordinate influx of mass tourism in the form of daily arrivals from the peninsula and from cruise ships entering the lagoon, as well as a constant loss of residents, resulting in a monoculture that has affected the real estate market in a city that has no capacity for expansion other than the use of its public spaces for commerce. As Salvatore Settis recalls, Venice is thus an example not to follow but to observe with caution:

The future of the historical city is a great theme that is played not only in Venice and not only in Italy, but of which Venice can be assumed to be a supreme symbol. Every day it is increasingly urgent to ask how each city can merge its symbolic capital with the civic capital of citizens, translating it into a conscious right to the city and putting it to good use. How it can identify the physical form of the city and its ethical reason, how the right to the city, the social function of the property, the work of the citizens, can be their reason for being and their own project. If this can happen in Venice, it could happen everywhere. (Settis 2014)

\section{From Speculation to a Culture of Rehabilitation}

As a result of extreme tension in the markets, both in Europe and around the world, it is necessary to rethink the most basic principles that serve the city, its physical and social fabric, and its urban and architectural components; to look for formulas that, without losing oneself in self-referential localisms or avoiding the necessary renovation and improvement of our cities, their infrastructure and their ways of life, will enable us to reconcile an increasingly globalised economy with the local culture.

Given an increasingly urban population, identifying a city model that includes territorial, urban, environmental, 
and social compatibility requires a response to current and impending challenges. Strengthening the concept of 'from speculation to a culture of rehabilitation' has a special meaning in those European cities that are experiencing imbalances, but it is also relevant in cities that, while retaining a high heritage value, are undergoing great transformations that invariably influence both tangible and intangible heritage ${ }^{4}$. Faced with not only the environmental waste but also the social, cultural, and economic damage that the real estate bubble has produced, it is necessary to aim for a more sustainable territory, for a compact city that enables us to repopulate the historical centres and socially revitalise the neighbourhoods, and for the rehabilitation of the built environment and public spaces as a 'collective courtyard', promoting energy efficiency in the housing stock and supporting the sustainable urban rehabilitation of public buildings and degraded urban sectors, such as industrial areas that are in disuse. As urban regeneration processes in the interior of the city, three actions can give some guidelines.

1. Rehabilitation versus new construction: it is necessary to prioritise urban regeneration and the rehabilitation and densification of the existing city, with special attention paid to the heritage city that existed prior to the new construction and the occupation of territory whose environmental consequences are especially significant and evident. The unsustainability of the new conurbations, which have been based on creating a greater ecological footprint and slavery to the private car, and therefore an unsustainable mobility from the social and environmental points of view, must find an answer in the densification of the existing city. The improvement of large residential neighbourhoods with low energy efficiency and the regeneration of historic centres to maintain their residential value are essential to upgrading the heritage that is contained in both their material and intangible components.

2. Reactivation versus rehabilitation: rehabilitation must encompass not only the physical dimensions of the built environment, but also the economic, environmental, and social aspects of the space to achieve a multiple vision that includes the environment and, most importantly, the people. The concept of reactivation extends this intervention to those components that enable the sustainability of an urban regeneration program that must continually compensate investment in the physical improvement of buildings and public spaces that can generate a local microeconomy. There will be no urban and environmental sustainability without the social sustainability of urban transformations. In this sense, the commitment to expanding the stock of public housing in heritage areas allows us to maintain a vulnerable social sector in the existing city, thereby guaranteeing the social mix that is necessary to reactivate a neighbourhood at risk of gentrification.

3. Holistic versus sectorial rehabilitation: rehabilitation must also encompass innovation in terms of the improvement of the residential fabric, including new forms of life that need renewed spaces to make them compatible with their heritage value and the incorporation of services that allow the daily life of the residents (e.g., health centres, local businesses, schools, and leisure facilities), as well as the regeneration of public spaces in which the right to the city is mainly exercised and where there is a daily tension between tourism and residential values. The consideration towards the housing policy in a sectorial manner, understood as merchandise, has been an important cause of real estate speculation. Therefore, embracing a comprehensive vision of urban transformation today makes it possible to alleviate the tourism monoculture in areas of high heritage value. A holistic vision can adapt the urban regeneration action with the services that allow to preserve the residential and daily uses, partially inserting the tourist use that, properly directed, can generate a local economy.

\section{Córdoba and the PAX-Patios de la Axerquía Strategy}

The case of Spain is of special interest in terms of an analysis of the consequences of the real estate bubble that generated an outscaled and inaccessible housing stock. This came along with an exacerbated property culture, meaning that families bore the cost of a high financial debt for the acquisition of housing. The environmental unsustainability of the model is compounded by its social unsustainability, as evidenced by the number of evictions. Today, the attention of the real estate market is directed elsewhere, specially in the interior of the city and often with the temporariry use of the touristic industry as a driver, in a process that takes advantage of the economic crisis condition of the people. For example, the exponential growth in tourist accommodation in private dwellings, marketed as part of a 'sharing economy', which should be an economy shared by all citizens, has introduced the financial market to this area and is reconfiguring in an unsustainable way the relationship between the city and its people through the phenomenon of gentrification or, 

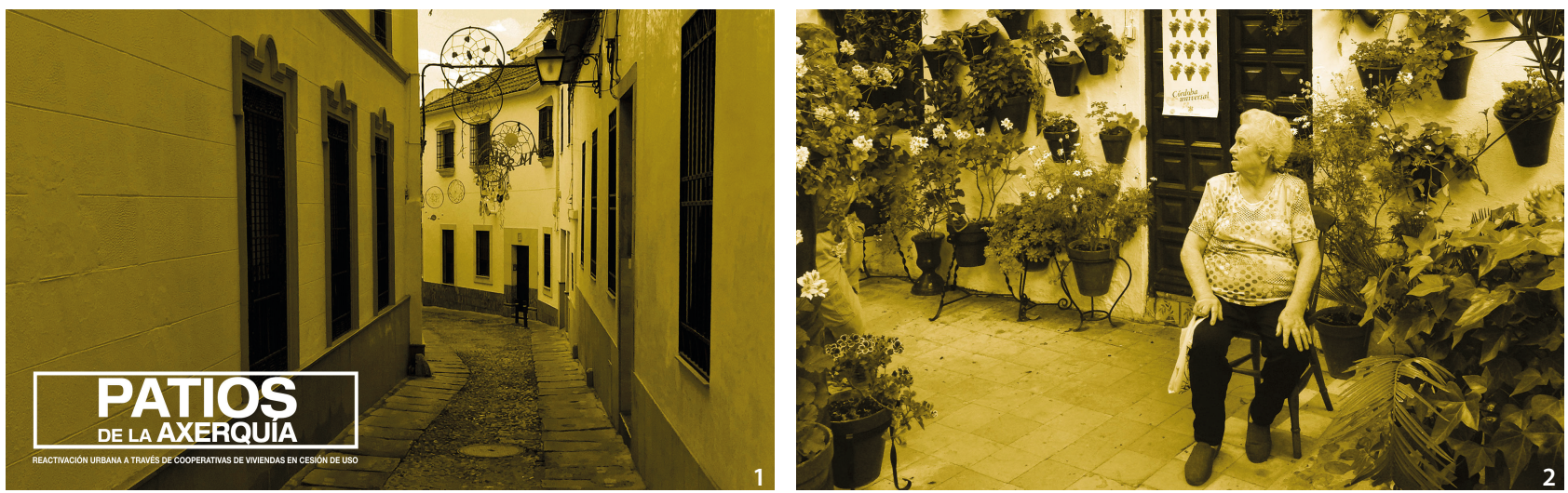

Figure 1 A typical street of Axerquia and PAX logo (Source: PAX).

Figure $2 \mathrm{~A}$ typical patio house of the Axerquia with an old woman living alone (Source: Carlos Anaya).

rather, touristification. Perhaps it can be said that unfortunately, Spain has moved from a real estate bubble to a tourism bubble.

If, as Zygmunt Bauman says, 'the city today has become the main laboratory in which local solutions to global problems are sought, designed, experimented and put to the test' (Bauman 2014), keeping Venice in mind, we must identify the mechanisms that allow us to avoid the homologation of cities in a global market that affects local cultures. The turistification process is somehow making all the cities similar. The case of PAX-Patios de la Axerquia, originated in Córdoba, a city of 330,000 inhabitants in the Andalusian region in southern Spain, seeks to develop an appropriate strategy to achieve this goal ${ }^{5}$ (Figure 1).

The patrimonial urban dimension is especially present in cities whose historic centre has been declared a World Heritage Site by the UNESCO, as is the case in Córdoba. The city has recently received its fourth recognition by the UNESCO. In 1984, the Mosque of Córdoba, an extraordinary monument from the Umayyad period, was declared a World Heritage Site, to which a large part of the historic centre was added in 1994. In 2012, the UNESCO recognised the Fiesta de los Patios de Córdoba as intangible heritage, and in 2018 the Caliphal City of Madinat al-Zahra was added to the World Heritage List. With a growing tourism industry and very little industrial activity, Córdoba is now transforming itself and, even for now reduced to the area around the Mosque, is gradually becoming gentrified, a process that, as seen in other cases such as Lisbon, can suddenly accelerate if the conditions in terms of public regulation and investment are favourable. Having witnessed what has happened in other cities such as Venice, Barcelona, and Lisbon itself, to mention just a few, Córdoba is now at a crossroad. It can either exploit its heritage value in a mercantile manner to produce immediate wealth, while risking negative consequences in the medium and long term, or it can introduce mechanisms for co-management between the city administration and the people suggested by the Faro Convention to make the necessary upgrade of the city to contemporaneity without losing the social value of heritage, as a common good.

Córdoba must take advantage of the opportunity to rethink its history by opening up to that paradigm shift that, incorporates heritage as an activator of the city for and thanks to the citizens. Throughout this process, it is essential to look for innovative approaches that prevent speculation within the city by updating the collective value of the patrimony, its economic potential, while continuing to recognise its social commitment and the collective memory that it treasures. In this sense, to ensure that Córdoba becomes a smart, sustainable, and inclusive city, PAX-Patios de la Axerquía is promoting an integrated project aimed at reactivating the sustainability potential of the centre, thus avoiding tourism-focused gentrification. PAX looks forward to implementing a different productive and cultural model, by multilevel co-management among the citizens. The most sustainable building is the one that which already exists, and the most sustainable city is one that does not occupy more territory, regenerates itself, and embraces its heritage, environmental, and social values as Mediterranean traditions. The presence in the historic city of many abandoned traditional houses, such as the casas-patio, requires innovative actions that ensure the reactivation of both the architectonic heritage and the intangible heritage by promoting co-habitation in neighbourly homes. The casas-patio is a courtyard house, either single-family or multi-family, as in the casa de vecino (neighbourhood house), which can be traced back to the domus in ancient Rome, and has been an important part 


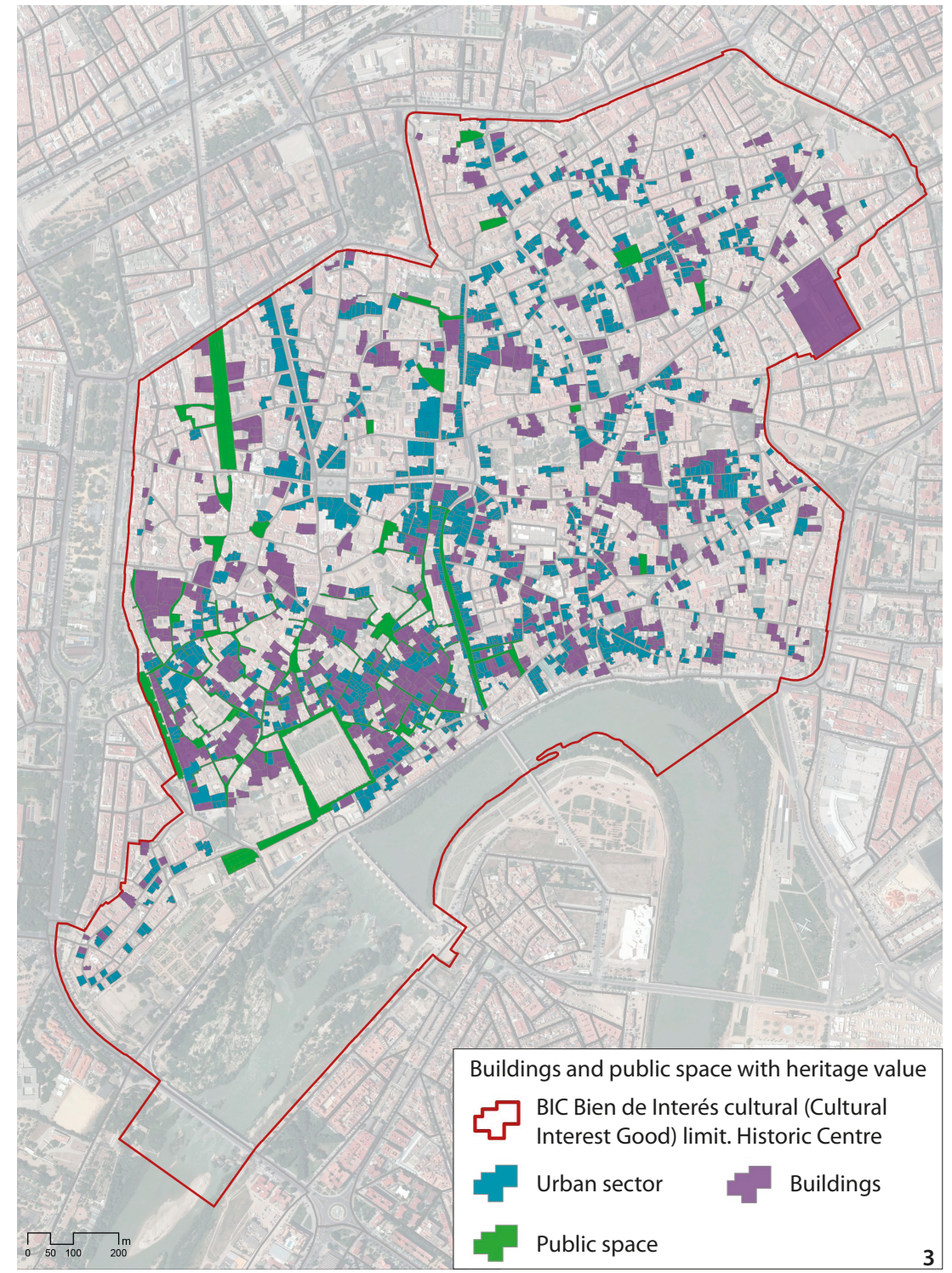

Figure 3 The Special Protection Plan of the Historical Centre of Cordoba. A document of the Urban Plan that establish the rule of intervention in the heritage part of Córdoba (Source: PAX). of the residential fabric in all Arabic cities. Offering both a meeting place and an interior garden, these patio-houses account for most of the urban fabric of Córdoba and encompass not only urban and architectonical values, but also the ecological components as green cells that guarantee both urban and social ecology (Figure 2).

PAX-Patios de la Axerquía, is a new style of governance in relation to urban regeneration incorporating social innovation in a heritage city. The strategy of urban regeneration through cooperative processes aims to use the empty patio-houses in the historic centre of Córdoba to provide permanent accommodation for local residents. The potential to re-use the existing city, in terms of both its material and intangible heritage values through revitalising abandoned patio-houses in a central neighborhood that is earmarked for future gentrification, has provided the impetus to generate a bottom-up strategy in terms of housing policy, heritage, urban regeneration, and social cohesion by updating the use of the courtyards through cooperative processes (Figure 3).

The housing cooperative is an instrument of the social solidarity economy that promotes co-housing for different groups of people. The constitution of a cooperative allows it to build or rehabilitate a building as a collective property in which each person/family who is part of the cooperative has the right to use of a part of the building without owning the property. The unique feature of PAX compared with other housing cooperatives that have been established as an alternative to property ownership and rental agreements is that it operates in a high-value heritage environment, updating the coexistence that has traditionally characterised the Mediterranean city, and aims to operate as a neighbourhood cooperative that unites housing, rehabilitation, and service cooperatives to generate a local microeconomy. 


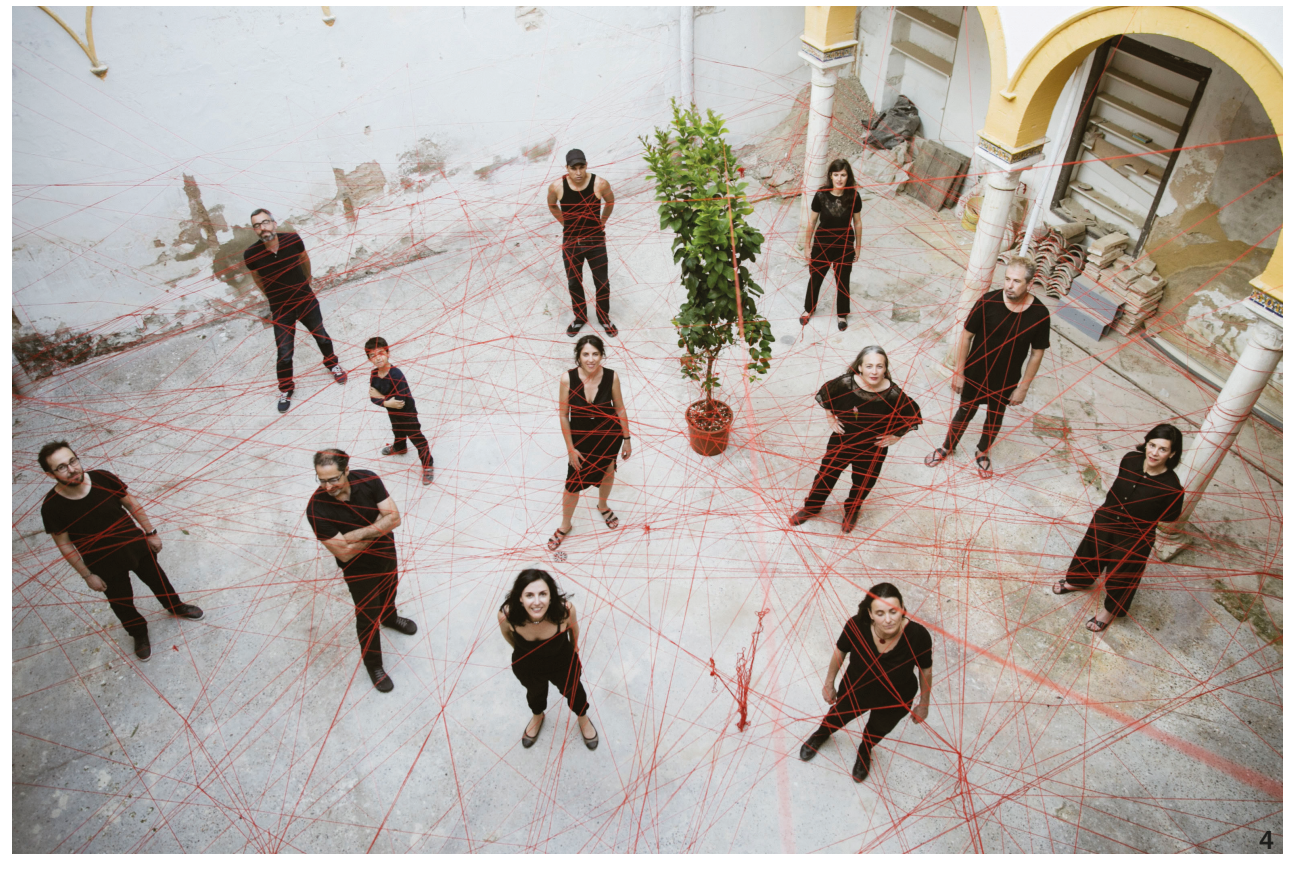

Figure 4 he PAX Team members during the installation done for the $15^{\text {th }}$ International Exhibition of Architecture. La Biennale of Venice (Source: Sergio Flores).
Recognised as part of the Faro Convention Network by the Council of Europe in 2018 for applying social heritage values in an urban context, PAX was invited to the $15^{\text {th }}$ International Architecture Exhibition La Biennale in Venice in 2016 (Figure 4) and has been declared a 'best practice' project by the Madrid City Council for improving the social economy in a neighbourhood (2018) and has been the subject of an article published in the internationally Italian magazine Abitare (Franzoia 2016).

\section{PAX as a Urban Regeneration Strategy through Social Innovation}

PAX was devised as an innovative urban project and a model to be repeated in other areas in Córdoba and other similar cities, especially European and Mediterranean cities, based on urban regeneration through social innovation. The Axerquia neighbourhood, an Hispanic Muslim area in the eastern section of the old town, was seen as the best place to conduct an experiment in governance involving local citizens opposed to its gentrification, updating its patrimonial, environmental, and urban values through social cohesion. The project has pursued the urban regeneration of a vulnerable area by the consolidation of a green-city, recovering the architectonic and intangible value of patio and forming a social and solidarity-based economy with:

1. Urban ecology: Through the re-use and densification of the historic city, strengthening of passive measures for traditional architecture and the patio-houses as a green urban system. In the current environment of increasing temperatures, a problem that is accentuated in urban Mediterranean areas, the aim is to create an efficient ecosystem in which mechanical refrigeration is minimised whilst providing increased comfort in both houses and public spaces thanks to knowledge and current technological resources.

2. Material and intangible heritage: Generation of public housing stock or cooperatives of local citizens using vacant patio-houses in the city centre to curtail gentrification. This strategy promotes the purchase of abandoned historic buildings for the densification of the city in the framework of housing, professional and restoration cooperatives, to enable the preservation of both the architectonic and environmental heritage and to maintain the local population. PAX promotes cultural activities in collaboration with other institutions and cultural and social organisations to facilitate the understanding of heritage in relation to people.

3. Housing and a social and solidarity economy: Governance and co-management involving citizens, social agents, and the public sector to form housing and service cooperatives that update the anthropological value of patio-houses and create local micro-employment. Parts of the patio-houses can be reserved for social emergency collectives or refugees, commercial local activities, non-profit organisations, or sustainable and responsible tourism that generates an income for the cooperative. It looks for increasing a sustainable economy network, linked to the market for heritage restoration 


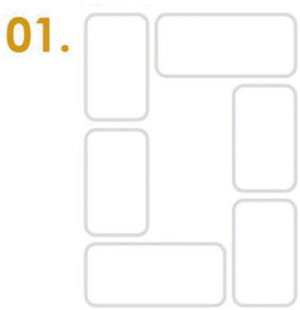

PATIO - HOUSE

+ high heritage value

+ bad condition

03.

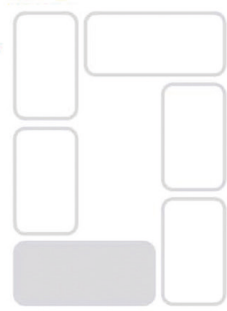

05.

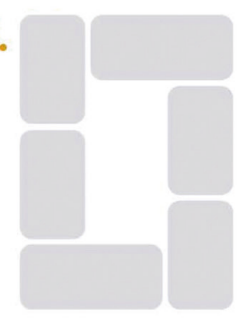

07.

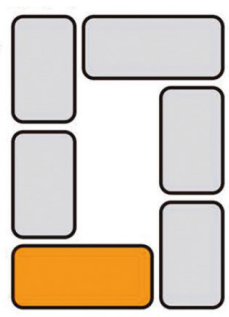

09

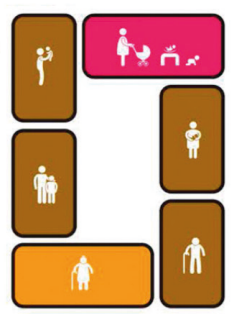

11

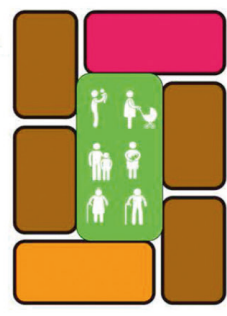

APARTAMENT RESERVED TO THE PREVIUOS

INHABITANT

APARTAMENTS FOR HEW GOOP MEMBERS

APARTAMENT RESERVED FOR:

social emergency situation/evictions

refugees and migrants

economic activity: microturism,

crafits, asociation, local comercial services

LIFE IN GOMMUNITY

SOCIAL GREEN
02.

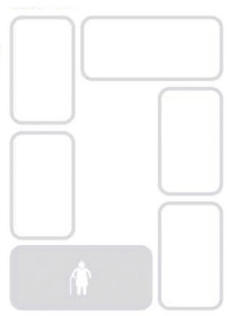

04.
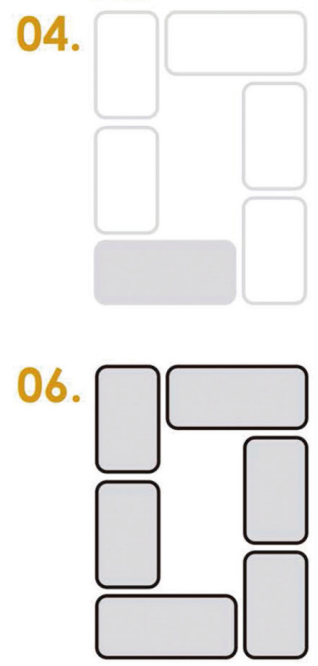

08.

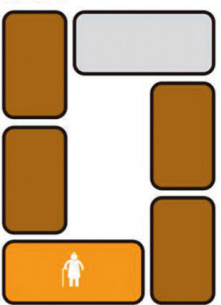

10.

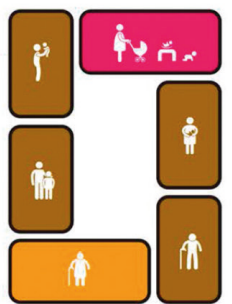

12.

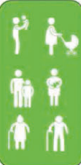

patio-house rehabilitated

life in community. Patio
PATIO - HOUSE

+ high heritage value

+ bad condition

+ underused
PATIO - hOUSE

+ high heritage value

+ had condition

+ underused

BUYING OR AGREEMENT WITH OWNERS

GONSTITUTION OF THE GOOPERATIVE

PATIO-HOUSE

+ high heritage value

+ bad condition

+ underused

BUYING OR AGREEMENT WITH OWNERS

GONSTITUTION OF THE GOOPERATIVE

RIGHT OF USE TO THE GOOP MEMBERS

BEHABIITATION

APARTAMENT RESERVED TO THE PREVIUOS

INHABITANT

APARTAMENTS FOR HEW GOOP MEMBERS

APARTAMENT RESERVED TO THE PREVIUOS INHABITANT

APARTAMENTS FOR NEW GOOP MEMBERS APARTAMENT RESERVED FOR:

social emergency situation/evictions refugees and migrants

economic activity: microturism, crafts, asociation, local comercial services

IIFE IM GOMMUNITY

APARTAMENT RESERVED TO THE PREVIUOS INHABITANT

APARTAMENTS FOR NEW BOOP MEMBERS

APARTAMENT RESERVED FOR:

social emergency situation/evictions

_refugees and migrants

economic activity: microturism.

crafts, asociation, local comercial services

LIFE IN GOMMUNITY

SOCIAL GREEN

GREEN GELI

apartament reserved to previous inhabitantes 
and local activities to improve the residential uses (Figure 5).

PAX opens a new gateway to sustainable urban restoration. Based on the empowerment of citizens as managers of their habitat, the proposal for urban regeneration of the historic centre contributes to their understanding of a more socially and environmentally sustainable and energy-efficient model adopting an integrated approach than the one that is provided by a city that is continually expanding to consume more territory. In response to the challenges that the project faces, PAX has established a series of goals:

1. Promotion of changes toward a culture of heritage and energetic restoration currently in place in the city that halt territorial speculation in the urban environment, instead promoting heritage and environmental regeneration in the historic centre, along with social reactivation.

2. Enhancing public housing stock through the acquisition of abandoned properties in the historic centre for restoration, thereby contributing to the city's densification, retaining the local population and signaling the worth of the casas-patio, which symbolises the traditional urban structure in the neighbourhood and provides a means of interaction amongst residents that can and must be retained.

3. Dissemination of information through local meetings with stakeholders to promote the concept of a heritage community as a cultural tool that can be used to recognise the social value of heritage and the coresponsibility between the public administration and the citizens for its future in the face of the speculative use of heritage within the tourism industry.

4. Promotion of the creation of residents' housing cooperatives through local laboratories and meetings that allow people to meet and decide on their form of cohabitation so that it is possible to find an appropriate patio-house for each collective and commence the process of incorporating the social economy into the urban regeneration of the centre, thereby avoiding gentrification.

5. Fostering the creation of local employment, especially female employment, through the inclusion of companies with social insertion projects and cooperatives linked to restoration, paying special attention to the local population as a means of creating employment in the neighbourhood, also enabling the possibility of self-built restoration interventions.

6. Enhancement of the network of public spaces such as the collective courtyards and acknowledgement of the environmental value the network of patio-houses represents in Córdoba, along with its role in the control and reduction of energy consumption using passive measures and vegetation in response to climate change.

7. Placing Córdoba at the forefront of European and international debate on sustainable urban reactivation of historic centres, as well as the inclusion of the social economy in the sphere of housing politics and urban regeneration so that this knowledge can be transferred to other Mediterranean and international projects.

\section{PAX as a Bottom-up Co-management Process}

In December 2017, an initial group of facilitators (the architects Gaia Redaelli and Jacinta Ortiz, together with the architect and anthropologist Carlos Anaya) founded the Association PAX - Patios de la Axerquía, which was formally created in April 2018, as a tool to drive the cultural and social innovation process and involve people and entities interested in experimental practice. The association will evolve into a 'second-level cooperative' (an urban body incorporating sociocultural and economic activities) when the housing cooperatives for each patio will be constituted. PAX also wants to include cooperatives of rehabilitation and to promote the heritage itineraries in the restored patio-houses to discover a different and more sustainable tourism and local economy. Due to its transferability to other similar contexts, PAX is also working in other cities, as in Italy.

PAX first identified empty houses of patrimonial value and initiated various local laboratories involving a range of stakeholders and citizens, and it is currently working with different groups that are in different phases of the process. Demographically, the groups consist of families in which the parents are about 40 years old, who want to share the educational values of the patio-houses with their children, and women of about 60 years of age who are willing to embrace a process of active aging, sharing their experience to shape the social initiatives that they manage. After discussing the needs of each community cooperative, PAX helps to find the best patio-house to meet those needs so that the material heritage (the building) is a consequence of the intangible heritage (people's way of coexistence). The relationship between PAX and the local neighbourhood associations is also very important because they guarantee the involvement of the residential community, which is a key to share the constitution of a 'heritage community' according to the terms of the Faro Convention. 


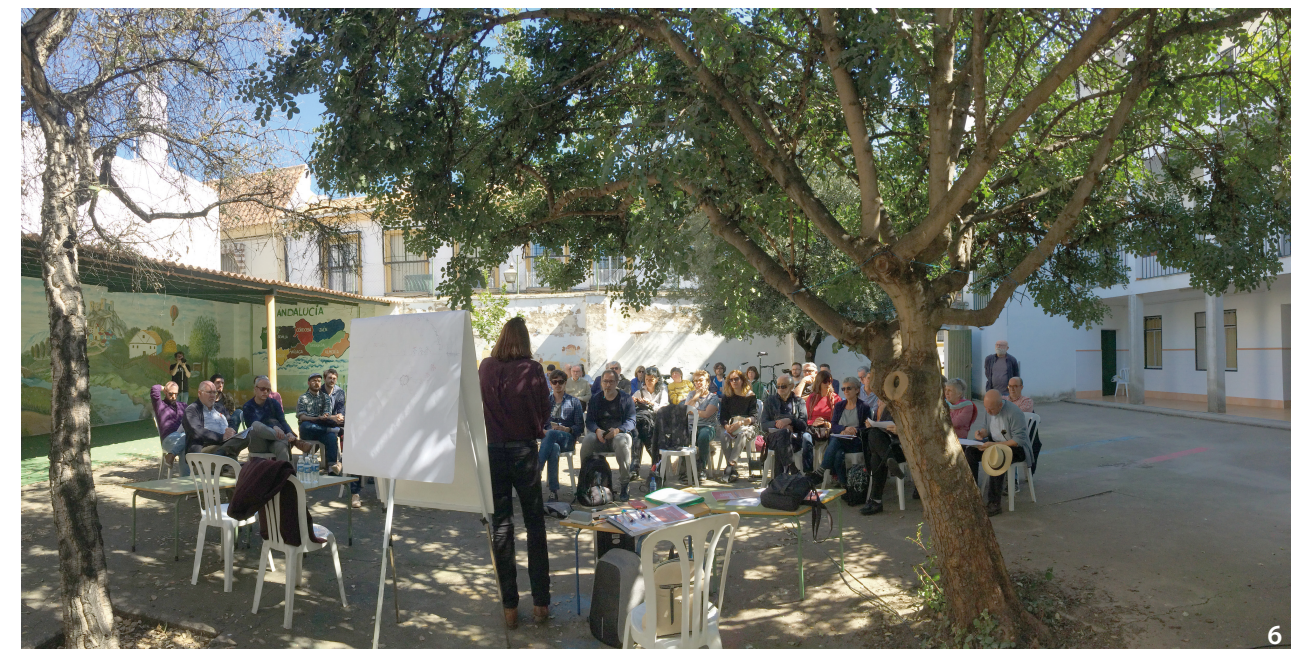

Figure 6 Meeting of the 'Right to the City' Forum in a courtyard of a public building on March 2019 (Source: the author).

In this sense, the cooperation with neighbourhood associations has been used to implement relationships of co-responsibility around the PAX project that, from the perspective of the social value of heritage, shares collectively a city model, as expressed by Harvey. In response to an invitation from the Axerquia Association, one of the most active associations in the city, the PAX team delivered a presentation outlining their strategy for the neighbourhood, and since then the two associations have been undertaking complementary activities based on the neighbourhood association's detailed knowledge of the area and the PAX team's experience in urban governance and regenerative action. In June 2018, based on this cooperation, the 'Forum for the Right to the City of Córdoba' was launched. This body is open to other neighbourhood associations, cultural entities, the university, ecologists, and the general public, who are invited to collectively define a city project for Córdoba. The Forum does not intend to be a formal institution, but rather a space for collaboration among different entities whose common goal is to preserve the right to the city of Córdoba, using actions based on activities in public spaces to influence the public administration. Since its creation, the Forum has held open meetings in public spaces, and among various initiatives, has generated a 'Citizen Agreement' that is divided into thematic areas and constitutes a road map for the city model. From the Urban Ecology to the Common Goods, from the Educating to the Inclusive City, from Economy and Tourism to Housing; from Mobility and public space to Active Citizenship, the tematical laboratories have drawn up a 'Citizen Agreement' which includes several statements and proposals for the city, including competencies of the administration, as well as the co-responsibility among the citizens. This document was presented in March $2019^{6}$ (Figure 6).
Even though the primary goal of PAX is the promotion of a bottom-up experience, it is also collaborating with various public and private institutions to facilitate the multidisciplinary and multilevel aspects of the strategy. The Andalusian Institute of Historic Heritage (Instituto Andaluz del Patrimonio Histórico), the public research centre of the regional Ministry of Culture in Andalucia, is collaborating with PAX to upgrade the Digital Atlas of Intangible Cultural Heritage with the patio-house data and to prepare training activities for the stakeholders. PAX is collecting data relating to both the material and intangible aspects of the patio-houses, such as drawings, documents, narratives, and photos, and will organise courses for local small enterprises in traditional materials and techniques that will be used to rehabilitate the heritage buildings. The University of Córdoba, in conjunction with the Etnocordoba research group, is working on the patio-houses from an anthropological point of view, and is collaborating with PAX on the social aspects in relation to the local community. The University of Seville, in conjunction with PAX, has conducted research on the ecology of the patiohouse, measuring its ecological benefits as a microclimate temperature moderator in a climate that reaches $45^{\circ}$ during two months of the year ${ }^{7}$. The Andalusian Institute of Advanced Sociological Studies (Instituto de Estudios Sociales Avanzados), in conjunction with PAX, is creating a map of gentrification in Córdoba using annual data on the residents and their demographic dynamics. The City Council of Córdoba is promoting a Housing Cooperative Forum and is interested in buying some patio-houses in the future to transform them into public housing in the historical part of the city.

The first PAX cooperative, named PAX Astronautas, was created in mid-2018, and used finance provided by 


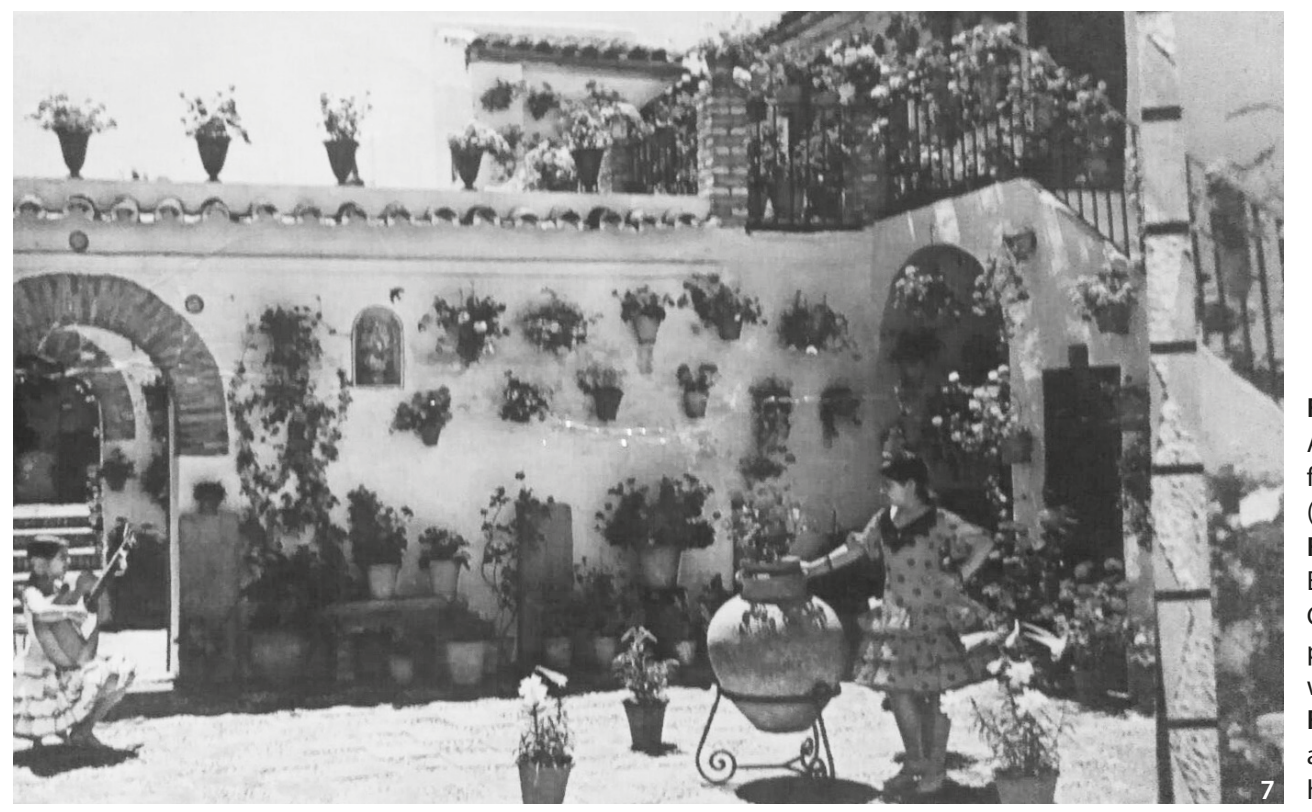

Figure 7 First PAX Cooperative. An historical photo when it was full of life and families living (Source: PAX).

Figure 8 Visit of Council of Europe members to the First PAX Cooperative Patio. PAX is now part of the Faro Convention Network (Source: Carlos Anaya). Figure 9 First PAX Cooperative actual photo before the PAX rehabilitation (Source: the author).
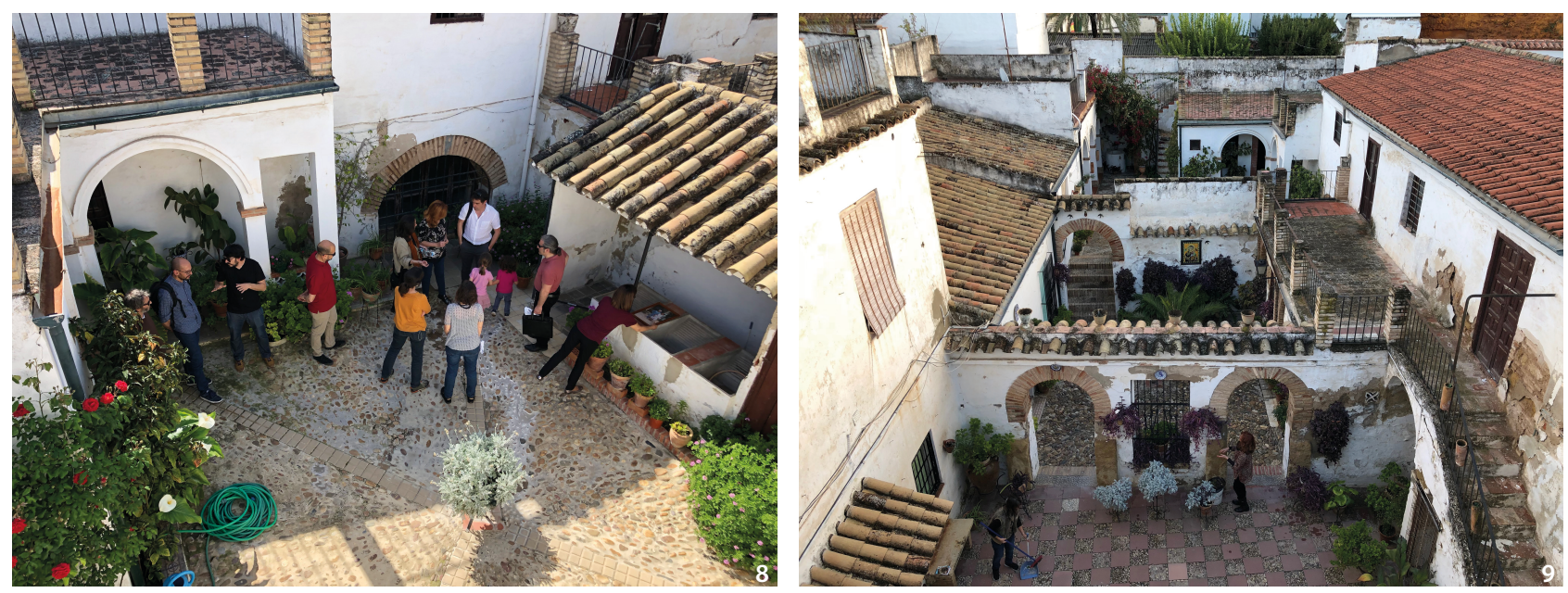

the Ethical Bank to purchase an impressive patio-house in Córdoba in January 2019. The house is one of the most interesting casa de vecinos in the northern Axerquia region, a special casa-patio that is suitable for multiple families. With three generous open-air spaces, which constitute an interior landscape that provides relief from the density of Cordoba's urban fabric, the house, which was built in the $18^{\text {th }}$ century, is quite well preserved, despite the changes that have been made over time by the various families that have lived there. Up to 16 families have lived in the house, generally in poor conditions, and the last owner living there died in the summer of 2018 (Figure 7).

The two daughters of the owner decided to sell the patio-house to a PAX cooperative rather than to an external investor who wanted to build a hotel because they recognised that PAX would guarantee a return to the kind of lifestyle they had enjoyed there as children. They understood the social value of the building, thanks to their

childhood memories. Six families, consisting of young couples and their children, will share the patio-house. The development of the rules of the cooperative in relation to the way in which the space is to be shared has been a democratic process involving a horizontal decisionmaking system. The PAX Association and the PAX Astronautas Cooperative have worked together in a synergistic way to address the economic, legal, urbanistic, and architectonic aspects of the project, paying special attention to the social component that has been displayed within other groups and cooperatives (Figure 8-10).

One of the fundamental aspects of the process, in addition to the anthropological value of the conformation of the cooperative and its relationship with the PAX association, is its financial viability. The traditional banking system did not assume the innovation that was requiered by the cooperative as collective property, which that introduced some particular needs at a legal and financial 


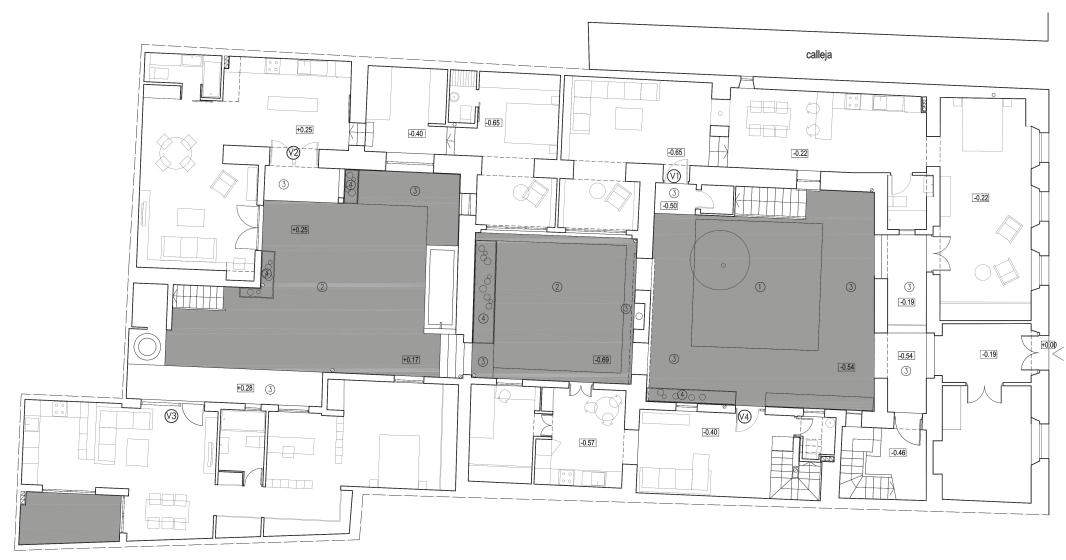

PLANtA gaja
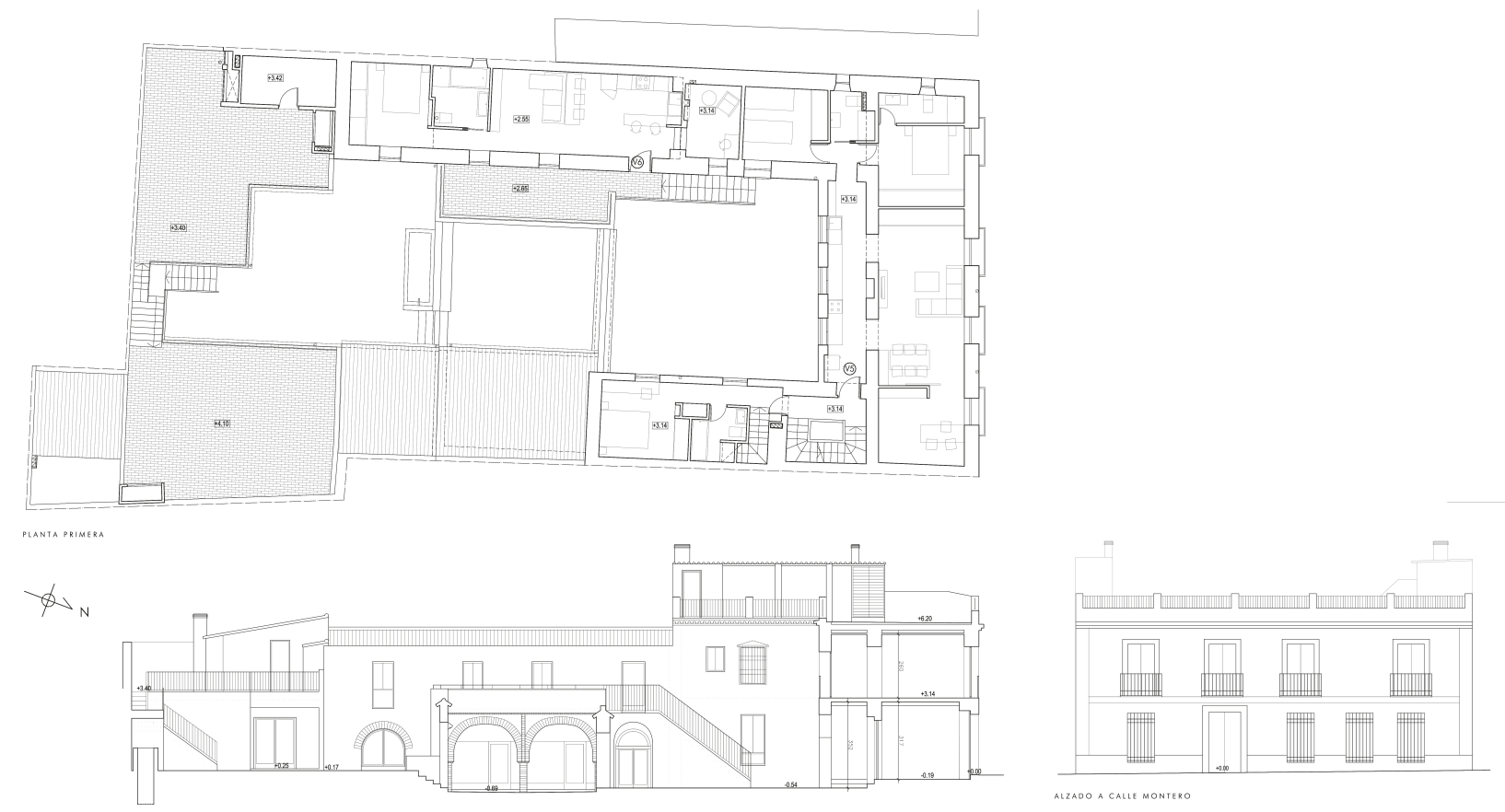

Figure 10 Plans and sections of the project of the First Pax Cooperative Montero street for 6 families (Source: Gaia Redaelli, Jacinta Ortiz, Carlos Anaya architects).

level. However, Fiare-Banca Etica finally understood the PAX strategy and their role for implementing a strategy of urban regeneration without speculative value from the financial sphere. Throughout the second half of 2018, the close collaboration between the PAX Association and the cooperative convinced Fiare-Banca Etica to provide the finance for the acquisition and rehabilitation of the first patio-house, which is located at 12 Montero Street.

A further decisive element is the physical rehabilitation of the building, which is being undertaken with a view to both preserving its heritage value and ensuring its suitability for the contemporary needs of the six families who will live in it. The executive project will implement both contemporary and traditional techniques in agreement with the architectural and constructive characteristics of the casa-patio. In this sense, the presence of the three patios will determine the design of the heating and cooling system also thanks to vegetation, especially during the hottest periods. In conjunction with the University of Seville, PAX has conducted energy monitoring to identify the most efficient active heating and cooling system, using the passive air circulation that these houses enable thanks also to the design and treatment of the vegetation of the patios. Once again, the activities in this pilot project are aimed at finding mechanisms that can be scientifically measured, can be reproduced in similar buildings to provide an urban ecology that is typical of the Mediterranean city, and can demonstrate how traditional architecture can 
and should contribute to a reduction of the effects of climate change in urban areas.

\section{Conclusions}

As a co-management, multilevel, bottom-up strategy for Urban Regeneration by Social Innovation in the context of the urban heritage of Cordoba, PAX is an experiment that in the next future will evolve into a start-up of urban governance facing gentrification processes. The most significant obstacle is the time needed to change the culture of rehabilitation at the local scale, as the global market and speculation are operating at a much higher speed. Nevertheless, the application of the PAX strategy in Córdoba can act as a 'laboratory', as Bauman states, that enables stakeholders to experiment with compatibility between the global economy and the local culture by adopting an innovative and holistic point of view, combining the physical and social dimensions, and working to achieve synergy between the city administration and the public based on the social value of heritage.

The architectural design of the first PAX patio-house will acknowledge the heritage value of the building while making it suitable for the contemporary way of life that the families that will live in it require. The ecological value will be the key to reducing the consumption of energy thanks to the presence of the patios and vegetation that encourages the passive circulation and refreshment of the air. The economic aspects will rely on promoting a small rehabilitation cooperative in Córdoba, including training activities designed to optimise the renovation of the building and facilitate new enterprises including responsible and sustainable tourism. Thus the social aspect is the most important aspect, because PAX is facilitating the updating of the heritage value within the collective memory of the people and community. The experiment is continuing, and PAX is seeking new communities to create new cooperatives in Córdoba and in other cities that need, as soon as possible, to start viewing heritage as a contemporary resource that can be used to guarantee smarter, more sustainable, and more inclusive cities.

\section{Notes}

1. Regarding the notion of gentrification, which it is not possible to address in detail in this article, see Smith (2002), Lees, Slater, and Wyly (2010), and Lees, Shin, and López Morales (2016). In the European context, see Observatorio Metropolitano de Madrid (Ed.) (2015), Indovina and Indovina and Nel.lo (2015), Nel. lo (2015), and Annunziata (2017).

2. See the results of the International Symposium on 'Heritage as a Common Good' that took place from 12-14 December 2018 in Córdoba in Spain. Organised by the Diputación de Córdoba and directed by Gaia Redaelli, this was a gathering of more than 40 experts from all over the world to discuss best practice in relation to the use of heritage in co-management processes.

3. 'Council of Europe Framework Convention on the Value of Cultural Heritage for Society' (CETS No. 199), adopted by the Committee of Ministers of the Council of Europe on 13/10/2005 and implemented on 01/06/2011. https://www.coe.int/en/web/conventions/ full-list/-/conventions/treaty/199

4. See Redaelli (2018) for the results of a study undertaken for the Municipality of Barcelona about best practice in European cities where public administration, universities, or social movement put in practice politics and anti-gentrification actions. The study analysed and compared best practices in Lisbon, Venice, Milan, Berlin, Madrid, Valencia, Marseille, Cádiz, Athens, Paris, Vienna, Naples, and London.

5. 'PAX - Patios de la Axerquía, estrategia de reactivación urbana a través de procesos cooperativos' was created in 2018 as Association PAX - Patios de la Axerquia, co-founded by Gaia Redaelli (president), Jacinta Ortiz (secretary), and Carlos Anaya (treasurer) as a multidisciplinary group. For more information, see Battistella (2017), Franzoia (2016), and www.patiosaxerquia.eu. PAX was originnaly elaborated for a Urban Innovative Actions funds in 2016 by Gaia Redaelli (Studio Redaelli Speranza architetti associati: Gaia Redaelli, Vito Redaelli, Anna Speranza), Direction. Jacinta Ortiz, Coordination. Carlos Anaya, Eva Morales, Felipe García, Manuel Rodríguez, team. Partners: Vimcorsa, Instituto Andaluz del Patrimonio Histórico, University of Córdoba, University of Sevilla, Faecta.

6. The 'Right to the City Forum' in Córdoba offers a multilevel and transversal way of collaborating among the various organisations. The main objective is to promote a consensus about the future of the city in a sustainable way, commencing with the heritage component. The main method is to cooperate and meet in a public space. The most recent meeting took place on 16 March 2019 in the courtyard of an unused public building, and involved discussion on the Citizens' Agreement. The architect and urbanist Itziar González, a specialist in urban conflict and common strategies for public spaces, and creator of the project involving 
the reactivation of the Rambla de Catalunya in Barcelona, outlined the experiences of the Parlament Ciutadà in Catalonia. For more information, see http:// cordoba.porelderechoalaciudad.eu/ and the interview by Marta Jiménez to Itziar González https://cordopolis. es/2019/03/24/itziar-gonzalez-a-la-administracionpublica-hay-que-meterla-en-un-patio-cordobes/

7. In collaboration with PAX, researchers of the University of Sevilla between July and August 2017 monitorised the bioclimatical condition of two patios in Cordoba detecting that temperature is between 6 and 12 less than on the outside conditions without any active system. See Rojas-Fernández J., Galán-Marín C., RoaFernández J. and Rivera-Gómez C. (2017). About the relation between Information and Communication Technologies and Intangible Cultural Heritage see the Synnes et al. (2019).

\section{References}

Annunziata, Sandra, ed. 2017. Anti-gentrificación nelle città (sud) europee [Anti-gentrification in (Southern) European Cities]. Urbanistica Tre 5 (13).

Battistella, Alessio. 2017. "The Sustainable Lightness of the Limit." Techne-Journal of Technology for Architecture and Environment 14 (2): 58-65.

Council of Europe. 1985. "Convention for the Protection of the Architectural Heritage of Europe."

Franzoia, Elena. 2016. "Cordova riscopre il patio mediterráneo." Abitare 558: 65-70.

Harvey, David. 2012. La ciudad rebelde. Del derecho a la ciudad a la revolución urbana [The Rebellious City: From the Right to the City to the Urban Revolution]. Madrid: Akal.

Indovina, F., and O. Nel.lo. 2015. "Gentrificación: Desastre, necesidad, oportunidad?. Notas para un uso crítico del concepto." [Gentrification: Disaster, need, opportunity? Notes for a Critical Use of the Concept.] In Capitalisme global i procesos de regeneración urbana [Global Capitalism and Urban Regeneration Processes]. Homenatge a Neil Smith. Col.loqui internacional, Espai critic, 14-16 September 2015, Barcelona.

Lees, Loretta, Bang Shin Hyun, and Ernesto López Morales. 2016. Planetary Gentrification. Cambridge: Polity.

Lees, Loretta, Tom Slater, and Elvin Wyly. 2010. The Gentrification Reader. New York: Routledge.

Lefebvre, Henri. 1975. El derecho a la ciudad [The Right to the City]. Barcelona: Penìnsula.

Nel.lo O. 2015. La ciudad en movimiento. Crisis social y respuesta ciudadana [The City in Movement: Social Crisis and Citizen Response]. Madrid: Diaz \& Pons

Observatorio Metropolitano de Madrid, ed. 2015. El mercado contra la ciudad. Globalización, gentrificación y politicas urbanas [The Market against the City: Globalization, Gentrification and Urban Policies]. Madrid: Traficante de sueños.

Redaelli, Gaia. 2018. "Atlas de la A-Gentrificación. Políticas y medidas para la sostenibilidad social en las transformaciones urbanas en ciudades europeas." [Atlas of A-Gentrification. Policies and Measures for Social Sustainability in Urban Transformations in European Cities.] Papers 60. Barcelona: Instituto de Estudi Metropolitans i Regionals de Barcelona.

Rojas-Fernández Juan, Carmen Galán-Marín, Jorge Roa-Fernández and Carlos Rivera-Gómez C. 2017. "Correlations between GIS-Based Urban Building Densification Analysis and Climate Guidelines for Mediterranean Courtyards." Sustainability 9 (12).

Saviani, Benjamim. 2018. "Restoration as a Social Cohesión Instrument: Vila Itororó in Central São Paulo." Built Heritage 2 (1): 66-76.

Secchi, Bernardo. 2013. La città dei ricchi e la città dei poveri [The City of the Rich and the City of the Poor]. Roma-Bari: Laterza.

Settis, Salvatore. 2014. Se Venezia muore [If Venice Dies]. Torino: Einaudi.

Smith, Neil. 2002. "New Globalism, New Urbanism: Gentrification as Global Urban Strategy." Antipode 34 (3): 434-457.

Synnes, K., Artopoulos G., Smaniotto C., Menezes M., and Redaelli G. 2019. "CyberParks Songs and StoriesEnriching Public Spaces with Localized Culture Heritage Material such as Digitized Songs and Stories." In CyberParks-The Interface Between People, Places and Technology:New Approaches and Perspectives, edited by Carlos Smaniotto Costa, 224-237. Springer.

UNESCO. 2003. "Convention for the Safeguarding of the Intangible Cultural Heritage." 